\title{
Foucault's Gulag*
}

\section{Jan Plamper}

On the evening of 21 June 1977, while French President Giscard d'Estaing was toasting the General Secretary of the CPSU and State President of the Soviet Union, Leonid Brezhnev, on the occasion of Brezhnev's first visit to France, an odd mix of people embarked upon a curious counter-celebration. At the small Théâtre Récamier a group of French intellectuals and Soviet dissidents gathered to stage a symbolic protest against what they saw as a political farce unfolding at the Élysée Palace. The dissidents present at the theater included Andrei Amal'rik, Vladimir Bukovskii, Natal'ia Gorbanevskaia, Leonid Pliushch, and Andrei Siniavskii; among the French guests were Simone de Beauvoir, Gilles Deleuze, André Glucksmann, Eugène Ionesco, and Jean-Paul Sartre. The French Left had come a long way from its Sovietophilic days, and this June evening might well have been the most harmonious that the two ends of the political spectrum had ever enjoyed together. The principal host and organizer greeted his guests: "We simply thought that, on the evening when M. Brezhnev is being received with pomp by M. Giscard d'Estaing, other French people could receive certain other Russians who are their friends." 1 These words came from Michel Foucault.

Foucault's masterminding of the Brezhnev counter-celebration was the culmination of an extended period beginning in the early 1970s, during which a number of more or less related issues preoccupied him. The year 1974 had seen the French publication of Aleksandr Solzhenitsyn's Gulag Archipelago. In its wake a group of so-called nouveaux philosophes (new philosophers) around the former Maoists André Glucksmann and Bernard-Henri Lévy had completed their break with Marxism - begun in the aftermath of 1968 - with Solzhenitsyn's evidence as ammunition. Foucault's own break with Marxism occurred during this period

\footnotetext{
* For comments on different versions of this paper I thank Jörg Baberowski, Victoria Bonnell, Laura Engelstein, Jochen Hellbeck, Stephen Kotkin, Irina Paperno, the editors of Kritika, and the Berkeley Russian History Working Group, especially Evgenii Polissky and Reginald Zelnik.

${ }^{1}$ Michel Foucault, quoted in Bernard Brigouleix, "L'autre reception," Le Monde, 23 June 1977, 2. Cited in David Macey, The Lives of Michel Foucault: A Biography (New York: Vintage, 1993), 380. For accounts of the event at Récamier, see Macey, Lives, 378-81, and Pierre Rigoulot, Les paupières Lourdes: Les Français face au goulag. Aveuglements et indignations (Paris: Éditions Universitaires, 1991), 135.
}

Kritika: Explorations in Russian and Eurasian History 3(2): 255-80, Spring 2002. 
and he chose to enter an alliance of sorts with the nouveaux philosophes. In 1975 Foucault's Surveiller et punir (Discipline and Punish) came out, a book that marked his rupture with structuralism and the beginning of what is conventionally labeled his Nietzschean phase. Concomitantly, Foucault's method changed from earlier archaeology, aimed at the uncovering of deep-structural discursive formations, to genealogy, concentrating on "that which conditions, limits, and institutionalizes discursive formations," while shunning hermeneutics and causal inquiry altogether. ${ }^{2}$ Finally, Foucault engaged in tireless real-life political activism on behalf of Soviet dissidents.

This essay examines the relationships between these events - the discovery of the Gulag, the break with Marxism, the alliance with the nouveaux philosophes, the drift into Nietzsche's orbit, the adoption of the genealogical method, and anti-Soviet political activism. Its focus is on Foucault's attempts to write the Gulag into his analysis of prisons and Soviet Russia into his philosophy. I will try to show how Foucault at one point associated the Soviet Gulag with preEnlightenment mechanisms of punishment, at another with 19th-century bourgeois penal practices. The Gulag, I will argue, ultimately remained a paradox to Foucault, for methodological and epistemological reasons. First, the genealogical method effected a leveling of sources that made distinctions between different types of evidence impossible. Evidentiary distinctions, however, are indispensable to any analysis of the Gulag, even if it foregrounds micro-techniques of power at the expense of macro-politics or the question of causes. For example, a history of the Gulag based on public legal documents, one of Foucault's preferred source genres, would fail to capture a far greater number of life practices than ever imaginable in the case of France. Second, despite Foucault's lifetime project of historicizing foundational categories of modernity (subjectivity, authorship, in/sanity), the geographical delimitation of his analyses remained undertheorized and never ceased to be refracted through the prism of an underhistoricized East/West dichotomy. Russians have seen themselves, and have been seen by others, as belonging to either East or West or both of the two poles, or neither one of them. Russia has been, in short, the liminal case par excellence. As such it became one case over which Foucault's categories stumbled, a notion that seems to have occurred to Foucault himself (if the proliferation of the word "paradox" in his attempts to classify the Gulag is any indication). As a liminal case, Russia casts problems associated with the seemingly universal claims and applicability of Foucault's work in even sharper relief than wholly "Other" regions of the so-

\footnotetext{
${ }^{2}$ Hubert L. Dreyfus and Paul Rabinow, Michel Foucault: Beyond Structuralism and Hermeneutics (Chicago: University of Chicago Press, 1982), 104.
} 
called Third World, from where, in the context of post-colonial discourse, most decentering challenges to Foucault have so far emanated. ${ }^{3}$

I will first retrace Foucault's attempts to come to terms with the Gulag, Russia, and Marxism. For this purpose I will examine Discipline and Punish, the only case in which Foucault inscribed the Gulag into a book-length study, and various interviews and articles, assembled in the French four-volume collection Dits et écrits. ${ }^{4}$ I will provide extensive translated quotations in the hope that Anglophone scholars of Russia with an interest in Foucault may refer more easily to these otherwise scattered and fairly obscure texts. ${ }^{5}$ I will then turn to the tensions that arise when Foucauldian concepts, empirically grounded in the West, are applied to non-Western locales. Finally, I will revisit Laura Engelstein's article on Foucault, Russia, and the question of legality as well as the debate surrounding it and explore what Foucault's pronouncements on the Gulag, which were ignored at the time, contribute to this debate. ${ }^{6}$ Two caveats: this paper rests on the premise that no strict line can be drawn between Foucault's "philosophical" books and "journalistic" writings. It is also based on the assumption that one can establish patterns even in thought as wildly anti-systemic and disorderly "plurivocal" in the words of one commentator - as that of Michel Foucault. ${ }^{7}$

\section{2}

The first texts in which Foucault mentioned the Soviet Union appeared in 1971. They seem primarily concerned with tracing the cultural conservatism of the

\footnotetext{
3 By "decentering" I have in mind attempts to relocate the cultural frame of reference to another context, to move the Archimedean point from which utterances are made, for example, from French to Chinese culture.

${ }^{4}$ Foucault, Dits et écrits: Édition établie sous la direction de Daniel Defert et François Ewald avec la collaboration de Jacques Lagrange [hereafter abbreviated as DE] (Paris: Gallimard, 1994), 4 vols.: vol. 1, 1954-69; vol. 2, 1970-75; vol. 3, 1976-79; vol. 4, 1980-88. Unless otherwise indicated, translations are mine. Wherever texts were translated from other languages into French for this edition, I have tried to use the original-language texts.

5 Since these lines were written, selections of the French four-volume edition have appeared in a three-volume English-language edition. See Foucault, Selections: The Essential Works of Foucault, 1954-1984, trans. Robert Hurley et al. (New York: New Press, 1997-2000), 3 vols.: vol. 1, Ethics: Subjectivity and Truth (1997); vol. 2, Aesthetics, Method, and Epistemology (1998); vol. 3, Power (2000).

6 See Laura Engelstein, "Combined Underdevelopment: Discipline and the Law in Imperial and Soviet Russia," American Historical Review 98: 2 (April 1993), 338-53. The essay appeared in slightly amended form in Foucault and the Writing of History, ed. Jan Goldstein (Cambridge: Blackwell, 1994), 220-36.

7 Jan Goldstein insists on Foucault's "plurivocality." See Jan Goldstein, “Framing Discipline with Law: Problems and Promises of the Liberal State," American Historical Review 98: 2 (April 1993), 366.
} 
French Communist Party (Parti communiste français, or PCF) and its allied trade union, the Confédération générale du travail (CGT), to the Soviet Union in order to explain the cultural clashes between student revolutionaries and workers. These clashes came to the fore in 1968 as the students attempted to export their revolution from the cafés of the Latin Quarter to the factories of the Paris suburbs. ${ }^{8}$ According to Foucault,

French students, in fact, have to deal with a large, organized working class which, through its unions and political organizations, clamors its allegiance to Marxism: French workers are perhaps ready to listen to students and understand their struggle, but at the same time, French students have to fight the conservative influence of the Communist Party and the C.G.T. [...] One of the biggest disappointments we had involving the Communist Party and the Soviet Union is that they readopted almost entirely the bourgeois value system. One gets the impression that communism in its traditional form suffers from a birth trauma: you would think that it wants to recapture for itself the world at the time it was born, the world of a triumphant bourgeoisie; communist aesthetics is realism in the style of the nineteenth century: Swan Lake, painting which tells a story, the social novel. Most of the bourgeois values are accepted and maintained by the Communist Party (in art, the family, sexuality, and daily life in general). We must free ourselves from this cultural conservatism, as well as political conservatism. We must uncover our rituals for what they are: completely arbitrary things, tied to our bourgeois way of life; it is good - and that is the real theater - to transcend them in the manner of play, by means of games and irony; it is good to be dirty and bearded, to have long hair, to look like a girl when one is a boy (and vice versa); one must "put in play," show up, transform and reverse the systems which quietly order us about. As far as I am concerned, that is what I try to do in my work. ${ }^{\text {? }}$

Several months later Foucault echoed the same theme: "That is perhaps what has happened in the history of the Soviet Union: the seemingly new institutions were in fact conceived from elements borrowed from the preceding system. The reconstitution of a Red Army copied from the tsarist model, return to artistic

\footnotetext{
${ }^{8}$ On the relationship of the PCF to Eastern European communism, including the show trials as well as the East German and Hungarian uprisings, see Richard Sacker, A Radiant Future: The French Communist Party and Eastern Europe 1944-1956, ed. Michael Kelly (Bern: Peter Lang, 1999).

9 John K. Simon, “A Conversation with Michel Foucault," Partisan Review 38: 2 (1971), 196, 201.
} 
realism, to traditional family morality: the Soviet Union fell back into norms inspired by bourgeois society of the 19th century." 10 These and other assertions of a lineage from "the modern age" (19th-century "bourgeois" Europe) to the Soviet experience will resurface in Foucault's attempts to construct a history of the Gulag. ${ }^{11}$

Probably while researching Discipline and Punish in early 1972, Foucault first put Soviet penal practices in a larger European picture:

And today, for reasons still quite obscure to me, we are returning to a kind of general, undifferentiated incarceration. The Nazi concentration camps have introduced the bloody, violent, inhumane variant of this new incarceration - Jews, homosexuals, Communists, vagabonds, gypsies, political agitators, workers, all in the same camp. And today one sees the same thing taking shape in a more discreet, covered form, in a seemingly scientific manner. The famous psychiatric wards of the Soviet Union begin to function in this manner. ${ }^{12}$

In the same spring of 1972, Foucault said:

[W] hen a society, even a society as capitalist as Britain's, declares that there is no more incarceration, at least for demented people, I ask myself: does this mean that the other great half of incarceration, the prison, is going to disappear or is it on the contrary going to occupy the space left empty by the mental health hospital? Does Great Britain not do the inverse of what the Soviet Union is in the process of doing? The USSR generalizes the psychiatric hospital, it makes it play the role of prisons. Will Great Britain not be induced to expand the function of prisons, even if they are greatly improved? ${ }^{13}$

These pronouncements came at a time when Marxism, the sediment in which much of French thought had been embedded between the mid-1940s and 1956, had begun to erode. Marxist thought and Soviet-style communism owed their popularity during these years to the discrediting of Nazism and fascism, the Soviet victory in World War II, and a combination of uniquely French precondi-

\footnotetext{
10 DE, vol. 2, no. 98, "Par-delà le bien et le mal,” November 1971 (223-36), 234.

${ }^{11}$ For example: "[T] his has happened in the Soviet Union and in the popular democracies: a kind of society has been reconstituted which has been transposed from the bourgeois societies of the nineteenth century. The universalization of the model of the bourgeois has been the utopia which has animated the constitution of Soviet society" "Noam Chomsky and Michel Foucault. Human Nature: Justice versus Power," in Reflexive Water: The Basic Concerns of Mankind, ed. Fons Elders [London: Souvenir, 1974], 174.)

12 DE, vol. 2, no. 105, "Le grand enfermement," 25 March 1972 (296-306), 298-99.

13 DE, vol. 2, no. 107, “Table ronde," April-May 1972 (316-39), 319.
} 
tions, including an "attraction to violence, the uninterest in morality as a category of public behavior, [and] the curious and repeated addiction to German philosophical style," as Tony Judt has written. ${ }^{14}$ Only this background explains the blindness of French intellectuals toward the East European postwar show trials, toward those trials' undercurrent of anti-Semitism (witness the Slánský trial), and toward "the further revelations about the 'univers concentrationnaire' of Stalinism, as debated in the libel actions initiated by Viktor Kravchenko (January 1949) and David Rousset (November 1950-January 1951)."15 After 1956 the situation changed again: Eastern Europe was pushed to backstage, and the anticolonial liberation movements and "third-worldism" monopolized the attention of French intellectuals over the next decade.

It was in the wake of 1968 and the attacks on Marxism by former Maoists, but still before the death knell that came in the form of Solzhenitsyn's Gulag Archipelago (1974), that Foucault made his statements. ${ }^{16}$ Foucault's relationship to Marxism had been complex. In terms of his political sympathies, he had gone through the phases of a short-lived membership in the PCF (1950-53), with disillusionment settling in during the Doctor's Plot (1953), augmented during the Soviet Union's 1956 invasion of Hungary and his one-year stay in Poland (1958), and culminating in his 1975 outburst: "Don't talk to me about Marx any more! I never want to hear anything about that man again. Ask someone whose job it is. Someone paid to do it. Ask the Marxist functionaries. Me, I've had enough of Marx." 17 Here it is noteworthy that by the early 1970s he had already renounced Marxism, but that his most radical public condemnations came after the Solzhenitsyn bomb. Thus Foucault's first recorded statements on Russia were made in 1971-72 (followed by a three-year hiatus) and should be placed in the three intertwined contexts of the 1968 student revolution, his

\footnotetext{
14 Tony Judt, Past Imperfect: French Intellectuals, 1944-1956 (Berkeley: University of California Press, 1992), 7.

15 Ibid., 105. For more on the Kravchenko and Rousset affairs, see ibid., 112-16.

16 According to Judt, "[o]nly in the mid-1970s, when the revolutionary appeal of the nonEuropean world had itself run into the ground, did the attention of the intellectuals return to Europe. In doing so it was inevitably brought face to face with the enduring Communist legacy in the other half of the continent; only then, and only in part, was the agenda of 1956 taken up and addressed." See ibid., 285. On the various ways in which the memory of the French Revolution has structured the relationship of French intellectuals to the October Revolution and Soviet-style communism, see François Furet, The Passing of an Illusion: The Idea of Communism in the Twentieth Century, trans. Deborah Furet (Chicago: University of Chicago Press, 1999), esp. chap. 3.

17 Quoted in Didier Eribon, Michel Foucault, trans. Betsy Wing (Cambridge: Harvard University Press, 1991), 266. Foucault made this statement in late September 1975. It is recounted by Claude Mauriac, Le Temps immobile, vol. 3: Et comme l'espérence est violente (Paris: B. Grasset, 1976), 581.
} 
history of prisons, and his and other intellectuals' reassessments of Marxism's validity in theory and practice.

The year 1975 may some day enter the annals of French intellectual history as the year of prisons. In the spring of that year, Michel Foucault published Surveiller et punir. In April, Aleksandr Solzhenitsyn made a celebrated appearance on the national cultural talk show Apostrophes. In 1970 he had received the Nobel Prize; late 1973 had seen the Russian-language edition of his Gulag Archipelago, 1974 the publication of the first two volumes in French; but it was Bernard Pivot's popular television program that really put Solzhenitsyn and his exposé of Soviet camps on the French cultural map. ${ }^{18}$ Also in 1975, André Glucksmann published La Cuisinière et le mangeur d'hommes: Essai sur les rapports entre l'État, le marxisme et les camps de concentration (The Oven and the Man-Eater: An Essay on the Connections between the State, Marxism, and Concentration Camps).

The links among these three texts are numerous. They point from Solzhenitsyn to both Foucault and Glucksmann (though not vice versa) as well as from Foucault to Glucksmann (and vice versa). Foucault inscribed Solzhenitsyn's central metaphor of "archipelago" into the final pages of Discipline and Punish: "In short, the carceral archipelago assures, in the depths of the social body, the formation of delinquency on the basis of subtle illegalities, the overlapping of the latter by the former and the establishment of a specified criminality." ${ }^{19}$ (The context was the putative contrast between a pre-Enlightenment penal regime that allowed the peaceful interstitial existence of romanticized "outlaws" and an Enlightenment order that eradicated any such space, producing an ever differentiating group of "delinquents.") We know that the reference to Solzhenitsyn was intentional, for, asked about the proliferation of spatial metaphors in his work, Foucault replied in an interview in early 1976: "There is only one notion here that is truly geographical, that of an archipelago. I have used it only once, and that was to designate, via the title of Solzhenitsyn's work, the

\footnotetext{
18 On the electrifying and divisive impact of Gulag Archipelago on French intellectuals, precipitating a redrawing of political boundaries (with formerly Maoist soixante-huitards applauding Solzhenitsyn, orthodox PCF members and parts of the détente-conscious Right vilifying him), see the comments by Solzhenitsyn's French editor (Claude Durand, "Le choc Soljénitsyne," L'Histoire, no. 223 [July-August 1998], 66-68, esp. 67).

${ }^{19}$ Foucault, Discipline and Punish: The Birth of the Prison, trans. Alan Sheridan (New York: Pantheon, 1977), 301. Emphasis mine. The French original quotation reads: "En un mot, l'archipel carcéral assure, dans les profondeurs du corps social, la formation de la déliquance à partir des illégalismes ténus, le recouvrement de ceux-ci par celle-là et la mise en place d'une criminalité spécifiée." See Foucault, Surveiller et punir: Naissance de la prison (Paris: Editions Gallimard, 1975), 308.
} 
carceral archipelago: the way in which a form of punitive system is physically dispersed yet at the same time covers the entirety of a society." 20

In the following years Foucault embarked on a zigzag course in which he mostly associated the Gulag with the "modern age" (punishment of the soul), sometimes with the "classical age" (and corporeal punishment), but hardly ever considered the possibility of overlap, of superimposition - of any trajectory, in short, deviating from Western Europe. To recreate a sense of the turnabouts and friction involved in Foucault's attempts to situate the Gulag, ultimately resulting in his understanding of not understanding, we will retrace his crooked itinerary chronologically.

In a January 1976 interview with a Bulgarian dissident, K. S. Karol, Foucault placed the Gulag squarely in modernity. "The Soviet Union," he ventured, "punishes according to the method of the 'bourgeois' order... And far from transforming it, it has followed the toughest line of punishment; it has aggravated it and carried [it] to the worst." 21 Here, the Gulag emerges as an import of Western provenance, invented during the rise of the bourgeoisie in the late 18th century and put into place during its ascendancy to political power, adopted wholesale and carried to extreme forms by the Soviet regime:

It is undoubtedly true that the Soviets, while having modified the regime of ownership and the state's role in the control of production, for the rest have simply transferred the techniques of administration and power implemented in Capitalist Europe of the 19th century. The types of morality, forms of aesthetics, disciplinary methods, everything that was effectively working in bourgeois society already around 1850 has moved en bloc into the Soviet regime... Just as the Soviets have used Taylorism and other methods of management experimented in the West, they have adopted our disciplinary techniques, adding to our arsenal another arm - party discipline. ${ }^{22}$

Also in early 1976, Foucault, in a move that today would be considered classically "Foucauldian," but would hardly be associated with the Soviet Union as its

20 "Questions on Geography," in Foucault, Power/Knowledge: Selected Interviews and other Writings 1972-1977, trans. Colin Gordon (New York: Pantheon, 1980), 68. Original in DE, vol. 3, no. 169, "Questions à Michel Foucault sur la géographie," January-March 1976 (28-40), 32. Curiously, in the French version a footnote following "carceral archipelago" states that the metaphor was omitted from post-1975 editions of Surveiller et punir. David Macey already noted the intertextual link between Gulag Archipelago and Discipline and Punish, though not the interview and Foucault's profession that it was deliberate (see Macey, Lives, 336, 524 note 51).

${ }^{21} D E$, vol. 3, no. 172, "Michel Foucault: Crimes et châtiments en U.R.S.S. et ailleurs...," 26 January 1976 (63-74), 64.

22 Ibid., 65. 
historic referent, called for a shift of focus from crude state power to subtle power mechanisms spread throughout the social body. He cited the Soviet Union as a prime example of a country where on the macro-level the state had been overturned in 1917, yet the relations of power on the micro-level remained in continuity with the 19th century:

The administrative monarchy of Louis XIV and Louis XV, intensely centralised as it was, certainly acted as an initial disciplinary model. As you know, the police was invented in Louis XV's France. I do not mean in any way to minimise the importance and effectiveness of State power. I simply feel that excessive insistence on its playing an exclusive role leads to the risk of overlooking all the mechanisms and effects of power which don't pass directly via the State apparatus, yet often sustain the State more effectively than its own institutions, enlarging and maximising its effectiveness. In Soviet society one has the example of a State apparatus which has changed hands, yet leaves social hierarchies, family life, sexuality and the body more or less as they were in capitalist society. Do you imagine the mechanisms of power that operate between technicians, foremen and workers are that much different here and in the Soviet Union? ${ }^{23}$

About a year later, in 1977, Foucault reversed his course. He returned to positing a linkeage between the Gulag and pre-modernity: "Like all political technologies, the Gulag institution has its history, its transformations and transpositions, its function and effects. The internment practices in the classical age forms in all likelihood a part of its archaeology." 24 Here Foucault seems to be saying that Soviet penal practices are in continuity with pre-Enlightenment ("the classical age") disciplinary methods. In yet another turnabout that same year, however, in a review of Les Maîtres penseurs (The Master Thinkers), André Glucksmann's follow-up to La Cuisinière et le mangeur d'hommes, Foucault described both the Holocaust and Stalin's purges as belonging to modernity, with the Napoleonic wars at the root of the genealogical tree and the fin-de-siècle "colonial genocides" as their immediate precursors:

The decisive test for the philosophies of Antiquity was their capacity of producing sages; in the Middle Ages, of rationalizing dogma; in the classical age, of grounding science; in the modern epoch, it is their ability to lend reason to massacres. The earlier [philosophies] helped man to sup-

23 "Questions on Geography," 72-73.

24 See Foucault's 1977 written answers to a list of questions, published in English as "Powers and Strategies" in Power/Knowledge, 135. For the French text see DE, vol. 3, no. 218, "Pouvoirs et Stratégies," 1977 (418-28), 419. 
port his own death, the later ones to support [the death] of others. Over the last one-and-a-half centuries the Napoleonic massacres have had a heavy lineage. But another type of Holocaust has appeared - Hitler, Stalin (the intermediary between one and the other, and the model for the second, were no doubt the colonial genocides). Thus the Gulag, as the entire Left has wanted to explain it, not as wars, through the theory of history, at least by the history of the theory. Massacres, yes, yes; but that was an awful error. Let us therefore take Marx or Lenin again, compare them with Stalin, and you will easily see where the latter was wrong. So many deaths, it is evident, could not have come from an error of reading. 25

Starting that same spring of 1977, Foucault repeatedly voiced opinions about a first congress of psychoanalysts to be held in the Soviet Union in the fall of 1977. Queried if in "authoritarian states ... power is not exercised against but through sexuality," Foucault replied:

Two recent facts, seemingly contradictory. About 18 months ago China began a campaign against child masturbation, exactly in the style that Europe in the 18th century experienced (it hinders you from working, it dulls you, it leads to the degeneration of the species...). On the other hand, before the end of the year the USSR will convene, for the first time, a congress of psychoanalysts (it is necessary that it convenes these psychoanalysts because the USSR does not have any). Liberalization? Thaw of the unconscious? Springtime of the Soviet libido vs. the moral embourgeoisement of the Chinese? In the old-fashioned stupidities of Beijing and the new oddities of the Soviets I see above all a recognition of the fact that formulated and prohibited, spoken and forbidden (dite et interdite), sexuality is a relay (relais) which no modern system of power can do without. I fear, I fear: socialism with a sexual face. ${ }^{26}$

Foucault here starts with an apparent contradiction - China's anti-masturbatory policies, typical of the beginning of modernity, and the Soviet Union's liberalization associated with the revival of psychoanalysis (after its suppression from the 1930s onward). In truth, argues Foucault, both phenomena are equally related to the entrapping uses of sexuality in the modern age. Just like "socialism with a human face" is a contradiction in terms - humanism standing for the increased repression of human beings through modern disciplines like psychiatry and

25 DE, vol. 3, no. 204, "La grande colère des faits," 9-15 May 1977 (277-81), 278.

26 DE, vol. 3, no. 200, "Non au sexe roi," 12-21 March 1977 (256-69), 263. 
psychoanalysis - Foucault's pun, "socialism with a sexual face," is also meant to signify increased repression through more sophisticated techniques of power.

After the 1976 publication of La Volonté de savoir, the first volume of The History of Sexuality, Foucault took part in a discussion of his book with psychoanalysts and historians. The conversation again touched on the congress of psychoanalysts, but also on the allegedly French origins of the Gulag:

J.-A. Miller: Do you know that there is going to be a first congress on psychoanalysis in the Soviet Union?

M. Foucault: That's what I have been told. Are there going to be Soviet psychoanalysts?

J.-A. Miller: No, they are trying to get psychoanalysts from abroad...

M. Foucault: Then this is going to be a congress of psychoanalysis in the Soviet Union where the people giving talks will be foreigners! Incredible! Although... There was the international penitentiary congress in St. Petersburg in 1890, where a little-known French criminologist, M. Léveillé, told the Russians: "The whole world nowadays agrees that criminals are impossible people, born criminals. What should be done about it? In our countries, which are all small, we know how to get rid of them. But you Russians, who have Siberia, can you not put them in great labor camps and thereby at the same time put to value the extraordinary wealth of this land?"

A. Grosrichard: There were no labor camps in Siberia yet?

M. Foucault: No! I was very surprised.

D. Colas: But it was a place of exile. Lenin went there in 1898, he married there, he went hunting and had a good time. And there were also prisons there. Chekhov visited one on the island of Sakhalin. The massive concentration camps where people worked are a Socialist invention! More particularly, they were born out of initiatives like Trotsky's, who organized from the remains of the Red Army a kind of labor army; later this [labor army] founded disciplinary camps which quickly became places of convict labor (relégation). There was a mixture of will, efficiency through militarization, of reeducation, of coercion...

M. Foucault: Actually, that idea came from recent French legislation about relégation. The idea of using prisoners during their punishment for work or something else of use is as old as the prisons. But the idea that at bottom there are among delinquents those who are absolutely incorrigible and that they have to be eliminated from society in one way or another, yet still be made use of, that is relégation. In France, after repeat offenses, a criminal was sent to Guiana or New Caledonia and later 
became a colonist. This is precisely what M. Léveillé proposed to the Russians, to exploit Siberia. It is incredible, though, that the Russians had not thought about it beforehand. [...] In France we do not have a Gulag, but we have ideas. ${ }^{27}$

Given the dearth of historic references in Foucault's musings on Russia and the Gulag, it is quite possible that this instance of a Franco-Russian connection, probably discovered by Foucault during research on French penology in the late 19th century, served as the basis for those moments in which he saw Soviet penal practices in a Western, modern lineage. Needless to say, it shows a striking lack of familiarity with Russian history. Siberia was used as a place for convict labor, especially of those categorized as incorrigible, from the time of Peter the Great, if not the 16th century, long before the French established penal colonies in New Caledonia and other places. ${ }^{28}$ Siberian colonization and relégation à la russe, if you will, were intertwined before the French Revolution.

The Leningrad psychoanalytic congress also intersected with Foucault's political activism. Viktor Fainberg, a dissident émigré, used the opportunity that the congress afforded to campaign for a political prisoner's release from a psychiatric hospital in Leningrad and received support from a number of French intellectuals, including Foucault. In the context of Fainberg's campaign, Foucault gave this interpretation of the renewed sanctioning of psychoanalysis in the Soviet Union:

The first Congress of Psychoanalysis in the Soviet Union is to be held next October: all the psychoanalysts will be foreigners, but they are being brought in. Why bring them in, if not because it is suspected that what they have to say may be of some use? And I'm sure they are being brought in as "sexologists." That's to say, there's a real need - which is probably not very clearly realized. I don't think there's a little Machiavelli behind all that. Fundamentally, there is a need felt for "normalization" of the individual's behavior, a need to take charge of the individual's behavior through forms of authority that are no longer the administrative and police authorities of the KGB, but something much more subtle. [ . . . A socialist society in which individuals' sexuality is a problem of public health doesn't seem to me to be at all a contradiction in terms. It doesn't seem to me to be at all a structural impossibility. And I don't believe there's a necessary connection between socialism and prudishness. I can very well imagine a "socialism" appearing in which

27 DE, vol. 3, no. 206, “Le jeu de Michel Foucault," July 1977 (298-329), 325-26.

28 See the review of new Russian works on exile and katorga by Andrew Gentes in Kritika 3: 1 (Winter 2002), 140-51. I am grateful to Andrew Gentes for detailed information on this issue. 
people's sexuality is... J. P. Faye: ...A political function? M. Foucault: People are held in place by simple means, whether housing conditions, mutual observation, several families sharing one kitchen or one bathroom. ${ }^{29}$

In the same interview, incidentally, Foucault indicated that he was aware not only of the repression of homosexuals in the Soviet Union but also of the silence with which dissidents treated this repression in particular and sexuality in general. $^{30}$

Occasionally Foucault appeared to feel uneasy about subsuming all Soviet penal practices in his classical age/modern age scheme. In 1976 he once called the internment of political dissidents in psychiatric wards "singularly paradoxical in a country that calls itself socialist." 31 For mental institutions grow out of medical discourse, which deals with the treatment of pathologies, whereas political transgression should fall within political discourse and be "corrected" by explanation, persuasion, purification of the conscience. Political alterity should logically be subjected to sociology (and reeducation), not biology (and healing). Foucault further spoke of the paradoxical role of labor in the Soviet Union:

Strange polyvalence of labor: punishment, principle of moral conversion, technique of readaptation, criterion of improvement, and final goal. Hence its application, according to the same scheme, is even more paradoxical in the Soviet Union. Two things in one: or could the labor imposed upon prisoners (regardless whether general or political) be of the same nature as that of the Soviet Union's workers; but this unalienating, non-exploitative, socialist labor - must it be detestable for not being possible without barbed wire and watch dogs? Or this is below labor, labor as punishment; and should we believe that a socialist country

\footnotetext{
29 Foucault, Politics, Philosophy, Culture: Interviews and Other Writings, 1977-1984, ed. Lawrence Kritzman (New York: Routledge, 1988), 207-8. For the French text see DE, vol. 3, no. 209, "Enfermement, psychiatrie, prison," Oct. 1977 (332-60), 358. Here Foucault appears surprisingly blind to the microtechniques of power in the first socialist society. Foucault's insights into these microtechniques have been applied to Soviet society by Stephen Kotkin, Magnetic Mountain: Stalinism as a Civilization (Berkeley: University of California Press, 1995).

30 "J. P. Faye: Even among the dissidents, there is almost a reinforcement of this silence on sexuality, which is quite extraordinary. The typical case is Parajanov, for example, who suffers from an insuperable taboo. Foucault: Indeed you can't get a single Soviet dissident to say anything about Parajanov" (Politics, Philosophy, Culture, 206-7). Sergei Paradzhanov (1924-90), an Armenian film director, was sentenced to prison on grounds of homosexuality.

31 “Michel Foucault: Crimes et châtiments en U.R.S.S. et ailleurs... ," 68.
} 
carries out the moral and political reeducation of its citizens with a caricature, so devaluating of work? 32

Ultimately, this recurrent sense of paradox is an indication that Foucault understood not having understood the Russian-Soviet case. He also recognized that the Stalinist Terror could hardly be explained in the categories of the "bourgeois order." In response to a question about the reduction of brutality since the 1930s, Foucault mused:

You say that the terror has diminished. That is for sure. Underneath, however, the terror is not the zenith of discipline, but its failure. In the Stalinist regime, the police chief could be executed one day after leaving the council of ministers. No NKVD chief died in his bed... Let us say that the terror is always reversible; it turns back fatally on those who exercise it. Fear is circular. But from the moment when the ministers, police commissars, academics, and Party functionaries become irremovable and no longer fear for their lives, discipline will function in the open... I believe that the societies of the 18th century invented discipline because the grand mechanisms of terror had become both too costly and too dangerous. 33

Here, on an empirical level, Foucault saw that elements of pre-modernity - "the grand mechanisms of terror" - manifested themselves during Soviet modernity. Foucault finished by saying that in order to be appreciated, socialist countries would have to invent a form of power - neither classical nor bourgeois - that does not rely on fear. "That would be a novelty." 34

\section{வ $\alpha$}

We have come to an end in this set of quotations that show Foucault classifying the Gulag either as a pre-modern or a modern phenomenon (the latter classification clearly outweighing the former), though never "in between." I purposefully broke the chronological sequence to end on a quotation intimating that Russia might fit snugly only there - "in between." In the remaining pages I will further contextualize Foucault's pronouncements on the Gulag and probe specifically how they were influenced by Solzhenitsyn. I will then show which "epistemological" and "methodological" reasons account for Foucault's inability to accommodate the Gulag. Subsequently I will broach the larger issue of his Eurocentrism (including the problems it creates when Foucault is applied outside

\footnotetext{
32 Ibid., 70

33 Ibid., 69.

34 Ibid., 74.
} 
the West) and the general issue of the applicability of Western theory to nonWestern contexts. My penultimate task will be to explore how the foregoing changes the parameters of the debate over the applicability of Foucault to Russia in the early 1990s, which took place between Laura Engelstein on the one hand and Jan Goldstein and Rudy Koshar on the other. I will finally conclude that Foucault can indeed be fruitfully applied to Russian cases, but that his thought carries much hidden baggage, which is best brought into the open.

To recapitulate: we started with Foucault's borrowing of Solzhenitsyn's "archipelago" metaphor in Discipline and Punish. At first sight, the formal similarities between "archipelago" and Foucault's famous metaphor for the 19th-century disciplinary regime, namely power "dispersed throughout the capillaries of the social body" are so striking as to suggest equivalence of their referents, the Gulag and modern punitive practices. Moreover, Discipline and Punish's rhetorical gambit - the juxtaposition of regicide Damiens' 1757 graphic execution with Faucher's 1837 rules "for the house of young prisoners in Paris," detailing an epochal shift in punishment from the body to the soul - could be viewed as mirroring the relationship between Chekhov and Solzhenitsyn, The Island of Sakhalin and Gulag Archipelago, the single island and the all-encompassing archipelago. Natalia Pervukhin has noted a triple connection between Chekhov's and Solzhenitsyn's texts:

First, Solzhenitsyn alludes to Chekhov's world in general to establish a reference point, an example of normal human society, against which to contrast the reality of Gulag. Second, he refers directly to Sakhalin and compares the prevailing conditions of a pre-revolutionary penal colony with those of his own time. [... Third, t] he compositional innovation of Chekhov's book and its implication in the work of Solzhenitsyn represent the main connection between Sakhalin and Gulag because the genre of "literary investigation" actually originated with Chekhov. Chekhov invented a new genre in which to portray reality; he elevated facts and statistics to the same level of importance as his anecdotal short stories and the narrator's lyrical digressions. 35

The similarities between Discipline and Punish and Gulag Archipelago are, however, merely superficial. Solzhenitsyn perceived Sakhalin and the tsarist penal

\footnotetext{
35 Natalia Pervukhin, “The 'Experiment in Literary Investigation' (Čexov's Saxalin and Solženicyn's Gulag)," Slavic and East European Journal 35: 4 (1991), 493. For a structuralist suggestion that Gulag Archipelago may not first and foremost be intertextually linked with Chekhov but, together with other Gulag memoirs, belongs to the independent genre of "documentary prose," see Leona Toker, "Toward a Poetics of Documentary Prose - From the Perspective of Gulag Testimonies," Poetics Today 18: 2 (Summer 1997), 187-222.
} 
system that it represented as "the aborigines of the Gulag," as an idyllic precursor to the infinitely more horrible Gulag. ${ }^{36}$ While Solzhenitsyn's metaphorical pairing island/archipelago is primarily quantitative, implying a multiplication of horrors, Foucault's capillaries/social body metaphor is primarily spatial, connoting the spreading of discipline across a larger area. The shift from tsarist to Soviet penal practices described by Solzhenitsyn is cast in unabashedly normative terms (in line with his nostalgic view of pre-revolutionary Russia), while it would be a misreading to see the shift from a pre-modern to a modern penal regime treated by Foucault as carrying Solzhenitsyn-like normative (or nostalgic) overtones. This is not to deny that Foucault's narrative is normative, but to claim that it is normative in a different way than Solzhenitsyn's. ${ }^{37}$ When looking for alternatives to the present, Foucault consistently spoke of the need to invent new forms of power, albeit without specifying what these would look like, while Solzhenitsyn proposes a simple return to an Orthodox Russia centered in the sociopolitical institution of the zemstvo. ${ }^{38}$ While Solzhenitsyn's narrative is

36 “Aborigines," cited in Pervukhin, "The 'Experiment," 492.

37 It should be noted that from its publication, Discipline and Punish has held particular appeal to Marxists, who have misread it as an analysis of a superstructural shift from one type of crude power to another type of more subtle, more all-encompassing power, caused by the development of capitalism between 1750 and 1830. Foucault has invited this misreading, for insofar as he offers a causal explanation for the shift in penal practices, it hinges on capitalism: "With the new forms of capital accumulation, new relations of production and the new legal status of property, all the popular practices that belonged, either in a silent, everyday, tolerated form, or in a violent form, to the illegality of rights were reduced by force to an illegality of property. In that movement which transformed a society of juridico-political levies into a society of the appropriation of the means and products of labour, theft tended to become the first of the great loopholes in legality. Or, to put it another way, the economy of illegalities was restructured with the development of capitalist society... In short, penal reform was born at the point of junction between the struggle against the super-power of the sovereign and that against the infra-power of acquired and tolerated illegalities" (Discipline and Punish, 86-87). Causal explanation, however, was precisely the mode Foucault attempted to eschew with the genealogical method, applied for the first time in Discipline and Punish. Foucault's central question is not "why did this shift occur?" but "looking at punishment, how did power relations between people come to function the way they function today, and how did people envelop them with a discourse of truth, how, in other words, did they construct a science around punishment?" The passage quoted above is therefore best understood as the residual occurrence of something otherwise thoroughly expunged from the text.

38 One of Foucault's calls to change the present: "D. E.: People say you are fairly pessimistic. Hearing you, I would say instead you were rather optimistic. Foucault: There's an optimism that consists in saying that things couldn't be any better. My optimism would consist in saying that so many things can be changed, fragile as they are, bound up more with circumstances than necessities, more arbitrary than self-evident, more a matter of complex, but temporary, historical circumstances than with inevitable anthropological constants..." Foucault, Politics, Philosophy, Culture, 156. True, Foucault's consistent emphasis that his own tools for an analysis of power enable the formulation of new forms of power, coupled with a lack of specificity on the nature of these new forms of power, 
linear (and thus Hegelian), even if it progresses downward from "bad" Sakhalin to "worse" Gulag, Foucault's is avowedly non-linear, counter-Hegelian Nietzschean. Finally, the different metaphors point to a different status of evidence in Solzhenitsyn and Foucault. Solzhenitsyn's archipelago had a concrete geographical referent - the Solovetskii Islands or Solovki in the White Sea, where the first Soviet camp for political prisoners was opened in 1920.39 "Archipelago" for Solzhenitsyn is therefore both the multiplication of Sakhalin, the single island, and the spreading of the Soviet $U r$-Camp, Solovki, across the entire Soviet Union. Foucault's relationship to evidence was a complex one, but certainly not that of conventional historians.

When situating the Gulag, Foucault ran into paradox and was ultimately unsuccessful for reasons that I want to term methodological and epistemological -general reasons dramatized by the Russian case. Methodologically, Foucault espoused genealogy over archaeology around 1970. ${ }^{40}$ Archaeology, conventionally associated with Foucault's structuralist phase, is devoted to an unearthing of the structures and continuities (discourse) underlying cultural practices. ${ }^{41}$ Genealogy, in contrast, is directed at the discontinuities of cultural practices. More precisely, the genealogical method has at least two clusters of distinguishing characteristics. ${ }^{42}$ First, it is counter-hermeneutical. Genealogy does not strive to uncover hidden truths or deep meanings but rather seeks truth at the surface. Second, it is directed against essences, laws, and teloi. Genealogy resists Hegelian essentialism and the Marxist search for laws that drive history. It does not accept any metaphysical finalities, whether religious or secularized utopian. Corre-

suggests a quasi-utopian realm for the future akin to that proposed by such Enlightenment projects as communism. But this is too large an aporia to be explored in the confines of this paper.

39 Dmitrii Sergeevich Likhachev, who was imprisoned on the Solovetskii Islands from 1928-31, suggested the metaphor of the "Gulag Archipelago" to Solzhenitsyn as a title for his work. See Likhachev, "Solovki 1928-31" in Fol'klor i kul'turnaia sreda GULAGa, ed. Vladimir Solomonovich Bakhtin and Boris Nikolaevich Putilov (St. Petersburg: Fond "Za razvitie i vyzhivanie chelovechestva," 1994), 165.

40 Dreyfus and Rabinow reject the ideal-typical construction of Foucault's Structuralist, Nietzschean, and Kantian phases and stress that "[t]here is no pre-and post-archaeology or genealogy in Foucault" (Dreyfus and Rabinow, Foucault, 104; emphasis in original). But they concede that the "weighting" of his methodologies changed.

41 For a convincing argument that "discourse," at least up to and including The Order of Things, was analogous to and grew out of Saussure's structure, langue, and that "archaeology" was the name Foucault ascribed to the method for excavating the deep-structural formation of discourse, see Manfred Frank, "Was ist ein 'Diskurs'? Zur 'Archäologie' Michel Foucaults," in Frank, Das Sagbare und das Unsagbare (Frankfurt am Main: Suhrkamp, 1990), 418, 424.

42 See Foucault, "Nietzsche, Genealogy, History," in Foucault, Language, Counter-Memory, Practice: Selected Essays and Interviews, ed. Donald F. Bouchard (Ithaca, NY: Cornell University Press, 1977), 139-64; Dreyfus and Rabinow, Foucault, 104-17. 
spondingly, it has no concern for origins and ends, as can be discerned on a formal level from the virtual absence of biological and organic metaphors (e.g. the topoi of life-stages - birth, adolescence, adulthood - so prevalent in national histories). ${ }^{43}$ As a result of these two sets of characteristics, texts appear to have no authors, factual events no agents. ${ }^{44}$ In comparison to historical monographs, moreover, Foucault's "scholarly apparatus" is thin - the notes are only the barest attributions to the source or consist of elaboration of his arguments. Citations never attempt to cover a totality of materials on a given topic or lead to a maximum number of related sources, as Foucauldian history never aims thoroughly to cover a topic "totally" and "definitively." A Foucauldian genealogist can cull equal meaning from any kind of source - archival or not, secret or not, authored or not. ${ }^{45}$

This leveling of sources may be acceptable for such Foucauldian projects as a history of Western subjectivity, but it proves disastrous for any historian working in a field that privileges traditional questions: what happened? Why? And who is to blame? Since the fall of the Soviet Union and the concomitant opening of the archives the field of Soviet history is to a considerable extent preoccupied with these questions. Phenomena like the Gulag and the Great Purges lend the questions of causes and perpetrators a special poignancy, since the answers put forward are immediately relevant not only to traumatized individuals but also to collective identities, as well as to legal-financial issues of compensation and resti-

43 One commentator wrote: "The genealogist/historian looks for beginnings, not origins. This for Foucault was an essential distinction. Origins imply causes; beginnings imply differences." Patricia O'Brian, "Michel Foucault's History of Culture," in The New Cultural History, ed. Lynn Hunt (Berkeley: University of California Press, 1989), 37.

44 The elision of authorship and agency stem from a recognition that authors and agents, like the modern subject, are cultural constructs of modernity, too: "I don't believe the problem can be solved by historicising the subject as posited by the phenomenologists, fabricating a subject that moves through the course of history. One has to dispense with the constituent subject, to get rid of the subject itself, that's to say, to arrive at an analysis which can account for the constitution of knowledges, discourses, domains of objects etc., without having to make reference to a subject which is either transcendental in relation to the field of events or runs in its empty sameness throughout the course of history" ("Truth and Power," in Power/Knowledge, 117).

45 To be sure, just as the boundary between archaeology and genealogy is more blurred than presented here, Foucault's attitude toward evidence was more programmatic than practical. His writings often lapse into traditional methods of historical verification as he seeks out documents representative of the dominant discourse. Gérard Noiriel maintains that genealogy never gained acceptance among historians because the relationship between history and philosophy was predicated on illusionary "interdisciplinarity" - the false belief in the possibility of disciplinary equality. Philosophical genealogy employs history as an auxiliary discipline to historicize philosophical categories like reason, while history can only conceive of itself as the discipline arbiting truth and ascribing other disciplines auxiliary status. See Gérard Noiriel, "Foucault and History: The Lessons of a Disillusion," Journal of Modern History 66: 3 (September 1994), 547-68. 
tution. In other words, because the Gulag and the Great Purges are a subject of public debate, constitutive of collective identities, and have an impact on contemporary legal-economic decision-making, historians, whether they like it or not, cannot keep their debates purely academic. Moreover, the function of public documents and other records differed sharply in the Soviet Union from documents in West European countries like France. Public legal documents often have no relationship to life practices. By establishing, for example, discursive continuities between the Stalin Constitution of 1936 and such constitutional documents as the French Declaration of Rights of Man, a genealogist would overlook an ocean of practices that were in direct contradiction to the Stalin Constitution. The kinds of evidence Foucault privileged himself - legal documents and scientific treatises - in the French case were predicated on a closer linkage between discourse and practices than ever conceivable in the RussianSoviet context.

Most important, while Foucault historicized foundational categories through which we view the world, he kept figuring this world through the lens of an essentialized binary opposition of East vs. West. For example, in his first book, Madness and Civilization, Foucault wrote:

In the universality of occidental reason there is the dividing line, posed by the Orient: the Orient, imagined as an origin, as the vertiginous point, where homesickness and the promise of return originate; the Orient that is offered to the colonizing reason of the Occident but that remains inaccessible, since it always remains the limit. [...] The Orient is for the Occident everything that the Occident is not, although it has to look for its original truth in the Orient. ${ }^{46}$

In The History of Sexuality, vol. 1, the West's scientia sexualis - sex as the object of truth - is juxtaposed by its Oriental Other, Eastern ars erotica - sex as the medium for truth. ${ }^{47}$ To be sure, in both cases Foucault is supposedly sketching an existing Western discourse rather making a claim to reality. But there is no indication that Foucault ever broke, or tried to break out of this Western discursive formation. Furthermore, within the dichotomous East/West structure, discursive and social practices flow unidirectionally from West, where they originate, to East, where they are emulated. The emulation of the West involves a time lapse but does not entail acculturation, i.e., the adaptation to local conditions and traditions, with hybrid outcomes.

\footnotetext{
46 See Foucault, Histoire de la folie (Paris: Librairie Plon, 1961), 10.

47 Foucault, The History of Sexuality, Volume 1: An Introduction, trans. Robert Hurley (New York: Pantheon, 1978), 57-58.
} 
Before turning to Laura Engelstein's treatment of Foucault's applicability to Russia it must be noted that recognizing the geographical delimitation of Foucault's universal claims as a problem has a long history, starting at least with Edward Said: "The most striking of his blind spots was, for example, his insouciance about the discrepancies between his basically limited French evidence and his ostensibly universal conclusions. Moreover, he showed no real interest in the relationships his work had with feminist or postcolonial writers facing problems of exclusion, confinement, and domination. Indeed his Eurocentrism was almost total, as if history itself took place only among a group of French and German thinkers." ${ }^{8}$ The literature that addresses this problematic aspect of Foucault's work can be broken down into three categories. The first shows how Foucault set up the objects of his inquiries in opposition to wholly Other Eastern counterparts that have figured prominently in the constitution of a Western sense of self. ${ }^{49}$ Although in interviews he professed a desire to study, for example, Japanese subjectivity and Japanese techniques of power, in collaboration with local Japanese scholars, ${ }^{50}$ Foucault never engaged in any such project, thereby saving himself, it might be added, from the conceptual pitfalls involved in radically decentering projects. ${ }^{51}$ Nor did he ever explore the process of the construction of Western subjectivity through reference to its Eastern Other in any depth. Nora Bierich pointedly asks: "Would this not always be the history of the West about the Orient, does one not risk a similar aporia as in Madness and Civilization, which made Foucault speak of the archaeology of silence?"52 Thus we can safely conclude that Foucault never went further than to intimate the importance of the East's alterity for the construction of Western subjectivity. Second, anthropologists mobilize, inter alia, Foucauldian notions of power in their analyses of those cultures that either Foucault or the West passed over in silence, that never figured as Others to the West. ${ }^{53}$ Third, Foucault has been applied to localities on Europe's margins - Czechoslovakia, Poland, Hungary, and Russia. ${ }^{54}$

\footnotetext{
48 Edward Said, "Michel Foucault, 1926-1984," in After Foucault: Humanistic Knowledge, Postmodern Challenges, ed. Jonathan Arac (New Brunswick, NJ: Rutgers University Press, 1988), 9-10.

49 See Nora Bierich, "Foucault und Japan," Deutsche Zeitschrift für Philosophie 42: 4 (1994), 633-42; Michel Leezenberg, "Power and Political Spirituality: Michel Foucault on the Islamic Revolution in Iran," in the special issue "Cultural History after Foucault," Arcadia 33: 1 (1998), 72-89.

50 Bierich, "Foucault und Japan," 636.

51 For skepticism regarding the feasibility of radical decentering, see Yuri Slezkine, Arctic Mirrors: Russia and the Small Peoples of the North (Ithaca, NY: Cornell University Press, 1994), 393-95; Jonathan Spence, The Question of Hu (New York: Knopf, 1988).

52 Bierich, "Foucault und Japan," 635.

53 See, for example, Bruce M. Knauft, "Foucault Meets South New Guinea: Knowledge, Power, Sexuality," Ethos 22: 4 (1994), 391-438. For a Marxist anthropologist's critique of Foucault's con-
} 
Laura Engelstein's work represents both a highly influential application of Foucault to one such locality and a treatment of the problems arising from applying Foucault to Russia. In a pivotal article, Engelstein argued that Foucault's real-life activism on behalf of liberation movements, including anti-Soviet ones (e.g. Solidarity in Poland) that worked toward the realization of such Enlightenment ideals as the autonomous individual, was separated by a deep chasm from his written output, where his ire was directed against the Enlightenment and its discontents - liberation manqué, an ever-increasing control of the individual via diffuse technologies of power.

But, no matter how complicated Foucault ultimately made the picture of modernity, he retained the distinction between old regimes, in which power emanated from the state, and the liberal, bourgeois society, in which power operates through "normalizing" mechanisms based on "scientific knowledge" and is implemented through disciplinary practices widely dispersed in the social body. Moreover, the chronological vector is never entirely lost: whatever the overlaps and collusions, Western nations have allegedly proceeded from absolutist monarchies, through Polizeistaat enlightened despotisms, to liberal states that delegate power through social self-regulation and control their citizens through the operational fiction of individual autonomy. ${ }^{55}$

Russia thoroughly confounds Foucault's chronological sequence, for "the Russian example represents the superimposition of the three models of power, chronologically separated (however imperfectly) in Foucault's scheme: the socalled juridical monarchy, the Polizeistaat, and the modern disciplinary regime." 56 In Engelstein's account, 19th-century Russia bore the features of both the French 19th-century "coercive, corporal, solitary, secret model of the power to punish" and the 18th-century "representative, scenic, signifying, public, collective model;" 57 both public torture of individual bodies and disciplinary, panoptic control of the entire social body; both the macrophysics and the microphysics of power. More than that, Russia also produced the liberal critics of the

cept of power, see P. Steven Sangren, “Power' against Ideology: A Critique of Foucaultian Usage,” Cultural Anthropology 10: 1 (1995), 3-40.

54 See Jonathan Arac, "Foucault and Central Europe: A Polemical Speculation," Boundary2 21: 3 (1994), 197-210. For an attempt to establish common intellectual concerns between Foucault and Patočka, the Czech philosopher, see Arpad Szakolczai, "Thinking beyond the East-West Divide: Foucault, Patočka, and the Care of the Self," Social Research 61: 2 (1994), 297-324.

55 Engelstein, "Combined Underdevelopment," 342.

56 Ibid., 343.

57 Foucault, Discipline and Punish, 131. 
old regime and, one might add, the Romantic critics of a new liberal-bourgeois regime, never translated into the Russian polity. Engelstein's tragic heroes are the liberals of late imperial Russia, ${ }^{58}$ who sought "not to displace an intrinsically ideological legality with the normative power of an equally inequitable and unfree disciplinary regime but to replace the alliance between discipline and the administrative state with a configuration that frames the operation of discipline within the confines of the law." The unintended outcome was frightening, indeed: "In the Russian-Soviet case, by contrast, the absolutist regime was succeeded by an administrative order that rejected legality and harnessed the professional disciplines to its own repressive ends, rather than a disciplinary society limited and controlled by the authority of the law." 59 Engelstein then proceeds to trace this trajectory by examining tsarist and Soviet law codes as well as the legal debates surrounding homosexuality and abortion. She remarks that "Foucault's hostility toward order (whether juridical or disciplinary) has dangerous political implications, some of which were played out on the Russian stage." ${ }^{0}$ In closing, she attributes these shortcomings to what one might call Foucault's Francocentrism: "For all his iconoclasm, Foucault, it must be remembered, lived not in Russia but in France, where he had the luxury to denounce the insidious intrusions of the disciplinary professions and the entangling effects of bourgeois liberation... Russia is a society that has yet to generate the luxury of a Michel Foucault to push it to consider the enticements of paradox." 61

\footnotetext{
58 Elsewhere, Engelstein defines Russian liberalism as follows: "By 'liberalism' I mean not the ideas and endeavors of political activists in a narrow sense but a configuration of attitudes and values dispersed among different social groups and in various cultural locations." See Laura Engelstein, The Keys to Happiness: Sex and the Search for Modernity in Fin-de-Siècle Russia (Ithaca, NY: Cornell University Press, 1992), 6 (and the following page for further specificity).

59 Idem, "Combined Underdevelopment," 344.

60 Ibid., 343.

61 Ibid., 353. In reaction to the appearance of Engelstein's article in Russian in 2001 a Moscowand Berkeley-based Slavist echoed this sentiment, yet with an interesting new twist: "This is a familiar feeling that many of us experienced under the Soviet regime: it seemed as if Western leftwingers, who were incriminating the tyranny of order in their civil society, were too well off and did not realize the value of the gift of freedom, of which we were deprived by totalitarianism." See Viktor Zhivov, "Chto delat's Fuko, zanimaias' russkoi istoriei?" Novoe literaturnoe obozrenie, no. 49 (2001), 85.
} 


\section{$2 \propto$}

I began this essay by recovering Foucault's own voice on the Gulag and Russia (from interviews and journalistic writings, conveniently collected in an indexed edition that was not available to Engelstein or her interlocutors in the early 1990s). I retraced his perplexing attempts to classify the Gulag either as a premodern or modern phenomenon, tried to place these classificatory pirouettes in their historical contexts, and ended with Foucault's acknowledgment of being unable to come to terms with the Gulag philosophically. After that, I expanded on one particular context, namely that of Solzhenitsyn and the nouveaux philosophes. I then turned to the methodological and epistemological problems that result from applying Foucault outside the West and illustrated, using the specific example of historical research on the Great Purges and Gulag in the Soviet Union, how Foucauldian history can become counterproductive.

In revisiting the debate between Engelstein and Jan Goldstein and Rudy Koshar below, my goal is not merely to show that Foucault's thought proves of little value when applied to the question of Russian legality in a construed test case. Rather, it is to shift the focus away from Foucault's putative anti-liberal politics and the larger theoretical problem of a country that does not fit his historical schema, both shortcomings emphasized by Engelstein, to what I consider more serious problems. ${ }^{62} \mathrm{I}$ have in mind the European coding of his categories and the emergence of the West as an absolute point of reference. The European coding of his categories - their particularity resulting from their formulation on the basis of empirical material exclusively from Europe - is difficult to discern. Foucault's analytical units (e.g. subjectivity, discourse, bio-power) do not disclose their hidden geographic vector and therefore create the impression of universal applicability. A careful distinction must be made: Foucault himself gave no indication that he considered his categories universally applicable. In fact, he once happily acknowledged that the Greeks did not conceive of a human subject, from

\footnotetext{
62 Engelstein notes the ambivalence of Foucault's attitude toward the law and liberalism (see Engelstein, "Combined Underdevelopment," 342). Other critics have been less discriminating and leveled the blanket charge of "neo-conservatism" at Foucault. Foucault himself gleefully remarked: "I believe to have been step by step, and sometimes simultaneously, put on most of the squares of the chessboard: Anarchist, leftist, flamboyant or crypto-Marxist, Nihilist, explicit or hidden antiMarxist, Technocrat in the service of Gaullism, Neoliberal... An American professor complained that he had invited a crypto-Marxist like me to the United States while in the press of the countries of the East I was denounced as an accomplice of dissidence. Not a single one of these characterizations is in itself important; taken together, however, they make sense. And I have to admit that this description suits me quite well." DE, vol. 4, conversation with Rabinow in The Foucault Reader, based on 1983 interview "Polemics, Politics, and Problematizations" (591-98), 593.
} 
which follows that the Foucauldian story of Greek subjectivity would be a story of silence. ${ }^{63}$

Engelstein's critique sparked a controversy and led two respondents, Rudy Koshar and Jan Goldstein, to charge her with reading Foucault contra Foucault, disregarding the fact that "Foucault is confused and/or plurivocal" and mistakenly "reduc[ing] him to univocality and then criticiz[ing] that single voice." 64 Ultimately, both sides in the dispute had a valid point. Engelstein selected one aspect of Foucault's thought and showed how, if applied to a different place, it has dangerous implications. Goldstein and Koshar criticized her for doing just that and insisted that Foucault's writings ought to be considered a toolbox from which one can borrow a method or trick and creatively apply it to whatever one

63 "I do not believe that an experience of the subject should be reconstituted where it did not find formulation. I am much closer to things than that. And because no Greek thinker ever found a definition of the subject and never searched for one, I would simply say that there is no subject" (Foucault, Politics, Philosophy, Culture, 253). The last word on the thorny issue of Foucault and Russia might go to Russians themselves. A recent issue of Russia's most fashionable journal of cultural theory and literary scholarship, Novoe literaturnoe obozrenie, not only featured an authorized translation of Laura Engelstein's article but also published a survey among Russian scholars about the applicability of Foucault's thought to Russian matters. This survey furnished answers as varied as that of a psychiatrist ("I think that he will be one of the most relevant thinkers for a long time to come") to a well-known Moscow classicist ("his style made me despair: in 19th-century France they shot you for such a style. Later I understood that this was nothing for French postmodernism"). See Iu. S. Savenko, "Perebolet's Fuko," Novoe literaturnoe obozrenie, no. 49 (2001), 89; Mikhail Leonovich Gasparov, "Vmesto otveta na anketu," in ibid., 21. According to a Moscow sociologist, "in the 1990s he was translated into Russian and underwent a reception 'from below' - as a classic, and not just any classic, but a fashionable one: this, above all, explains the parroting of his squeaky words instead of the labor-intensive digestion of his thought." Boris Vladimirovich Dubin, "Nevedomyi shedevr i ego znamenityi avtor," in ibid., 83. Whatever the misgivings of these scholars, Russian usage of Foucault on the ground - gestural and serious - is rampant and the vernacular is strong in the resulting amalgams. Just as Russian scholars travel back and forth to the West and transport ideas in their cultural baggage, we may actually have more cultural crosspollination than we thought. Indeed, we may not even have a one-way street from West to East, as suggested by examples as varied as Bakhtin's prominence in cultural studies, Alexandre Kojève's (Aleksandr Kojevnikov's) post-October export of a Russianized Hegel to France, and the Dostoevskii craze in Paris during the 1880s. As Foucault is transformed into a Cyrillic Fuko, his thought may live longer than we supposed - ironically outside the West.

64 See Jan Goldstein, "Framing Discipline with Law: Problems and Promises of the Liberal State," American Historical Review 98: 2 (April 1993), 366. The responses of Goldstein and Rudy Koshar ("Foucault and Social History: Comments on 'Combined Underdevelopment") are in ibid., 354-81. Goldstein also reproached Engelstein for relying almost exclusively on vol. 1 of The History of Sexuality and an influential essay entitled "Governmentality" in her portrayal of Foucault's positions. 
sees fit. ${ }^{65}$ In the test case construed by Engelstein, it seems to me, Foucault indeed proves of little value. This does not entail, however, that he is useless for every case, as Goldstein and Koshar read Engelstein to be implying. What is more, pulling Foucault's tools out of one's toolbox involves a selection process. The criteria for this selection should be founded on a careful study of the logic of the field to which one is contributing. ${ }^{66}$ Thus it is by no means my contention that none of Foucault's thought is applicable to Russia (or any other place). ${ }^{67}$ In fact, his writings on the self have inspired highly influential research on Russian and Soviet subjectivities. ${ }^{68}$ But in order to gain anything from Foucault beyond a murky sense of skepticism about the Enlightenment, we must, I am afraid, determine case by case if Foucauldian questions are applicable to it. This requires an awareness of the nature of the field into which we intervene. ${ }^{69}$ What discipli-

65 Later, Goldstein wrote: "While I always come to my material with the questions that $I$ have asked of it (rather than its seeking me out in my office and dumping its problems on my lap), I come equipped with a small company of theories that I regard as smart, astute, insightful by dint of the interpretive work they have been able to do in other settings as well as their heuristic value in helping to pose interesting historical questions to begin with. I then pick and choose among my theoretical repertory as the material seems to dictate." See Jan Goldstein, "Foucault's Technologies of the Self and the Cultural History of Identity," Arcadia 33: 1 (1998), 47.

66 To illustrate, Oleg Kharkhordin, a political scientist by training, has applied Foucault to the Russian case and is now being reproached by historians for not adhering to the disciplinary conventions of history. Specifically, historians have resented as far-fetched Kharkhordin's construction of continuities between medieval Russian Orthodox monastic confession practices and Soviet samokritika rituals. Foucauldian genealogy, however, invites precisely the construction of such discursive continuities; from a Foucauldian perspective, I believe, Kharkhordin cannot be faulted for anything. But it makes all the difference that Kharkhordin's book was targeted at an interdisciplinary audience and was received as such - an intervention in several disciplines. Given this combination of marketing and reception, Kharkhordin can be expected to adhere to at least some disciplinary conventions of history. See Oleg Kharkhordin, The Collective and the Individual in Russia: A Study of Practices (Berkeley: University of California Press, 1999). One critical historian wrote: "Kharkhordin realizes he cannot show any direct or documented link between Orthodox and Bolshevik practices: at this crucial juncture in his argument he can do little more than point to a 'startling similarity' between the two (54)" (Lars Lih, Slavic Review 59: 3 [Fall 2000], 704).

${ }^{67}$ For a different view see Judt, Past Imperfect, 299-301. "For outsiders, French intellectuals were and are talking heads: ideas and categories that are contingently attached to a sometimes charismatic body but quite detached from the cultural and political context of France" (300).

68 For examples, see Laura Engelstein and Stephanie Sandler, eds., Self and Story in Russian History (Ithaca, NY: Cornell University Press, 2000); Igal Halfin, From Darkness to Light: Class, Consciousness, and Salvation in Revolutionary Russia (Pittsburgh: University of Pittsburgh Press, 2000); Jochen Hellbeck, Revolution of the Soul: Soviet Diaries of the Stalin Era (Cambridge: Harvard University Press, forthcoming).

${ }^{69}$ I am using "field" with the dual connotations of "academic discipline" and Pierre Bourdieu's field theory, where a field is a segment of social life (e.g. science, the economy, or the arts) with a specific logic that structures the actions of the social actors who operate within it. 
nary conventions prevail in this field? Does it, for instance, privilege causal questions? Is the field limited to academia, or does it overlap with other fields, such as public debate about identities? Academic discussions in the field of the Stalinist purges, as I have tried to argue, are immediately relevant to extra-academic debates. These concern the role and public image of the secret service in presentday Russia, the question of monetary compensation for the repressed and their relatives, the individual identity of traumatized survivors, the collective memory of Russia, and many other issues. Even if it may not matter who is speaking, as Foucault kept telling us, it matters greatly where and to whom.

Institut für Osteuropäische Geschichte und Landeskunde University of Tübingen

Wilhelmstr. 36

72074 Tübingen, Germany

jan.plamper@uni-tuebingen.de 